\title{
Libraries of the Ancient World
}

\author{
Margaret Zarifeh
}

The origin of libraries lies in the practice of keeping records for future reference. In the $\mathrm{Bi}$ ble there are numerous allusions to the writing of books, and the places where they are deposited. In Ecclesiastes 12:12 Solomon said "of the making of books there is no end", and in Ezra 6:1 mention is made of "the house of the archives where documents were stored". To understand the development of libraries in the ancient world we must look first at the method of record keeping and how this was achieved.

The invention of writing together with a system by which documents could be distinguished and classified, coincided with the emergence of cities in Mesopotamia between the Tigris and Euphrates Rivers in 3500 BCE. The writing system known as cuneiform was used to represent several languages including Sumerian, Akkadian, Babylonian, Assyrian, Hittite and old Persian. Information was written on clay tablets. These comprised mainly official records covering matters such as legal contracts, tax as-

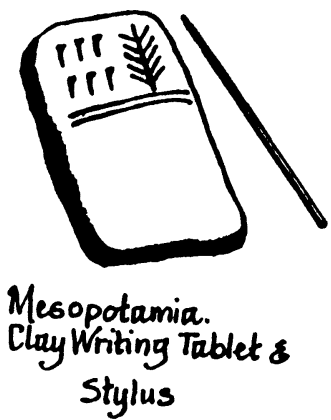
sessments, land management, treaties or astronomical data. With appropriate tools, impressions could easily be made on the smooth surface of the wet clay. These impressions became permanent whether the clay was kiln-fired or sun-dried and could retain the fine lines of the stylus. Styluses were made of reed, wood or other materials. Early clay tablets varied in shape: the very earliest tablets contained mostly numbers and were called bullae or tokens, their shape identifying different kinds of commercial transaction. As more sophisticated record-keeping systems developed, rectangular or square tablets came into use. A Babylonian workshop ca. $2000 \mathrm{BCE}$ discovered in the 1980s provided evidence of the different stages of tablet production. from the initial lumps of clay to the blank tablet ready for use. Tablet production and siylus manufacturing were an important aspect of many Mesopotamian libraries.

Certain important tablets reserved space in the last column for wither a summing up or the title of the composition. This section, which was called the colophon, provided the information which a modern book would present on its title page. It gave the title of the text, the names of the owner and the scribe, the date and remarks referring to the original from which the scribe had copied. Somerimes a text was said to be secret, and curses were added against those who would remove the tablet from its location without authorisation!

Scribal schools existed in Mesopotamia from about 2500 BCE. Information has been found written by scribes in Sumerian, giving detailed accounts of life in a scribal school. The examination of the parentage of these scribes shows that they were the sons of governors, senior civil servants, or priests. Occasionally a boy from a lower class might attend school if he was adopted by a wealthy man. The scribal school, or 'tablet house' as it was known, was sometimes attached to the ter ple. The student had to become proficient in Sumerian, which involved copying and memorising texts. A contemporary document that was found began with the question: 
Son of the tablet house, where did you go in your early days? The student replied:

I went to the tablet house; ...

I read out my tablet, ate my lunch, Prepared my fresh tablet, inscribed it and finished it, When the tablet was dismissed, I went home.

I entered my house. My father was sitting there.

I read over the tablet to him and he was pleased..

When the pupil graduated, he became a scribe or dubsar. Various levels of scribal classes existed with the dubsar girginakku of "master of the chassics" on the upper level down to the less exalted scribal occupations, such as weights and measures tabulation, where numeracy skills were more important than literacy skills.

The libraries of Tell Mardikh (Elba) and Tell Abu Salibih (near Nippur) dating to the middle of the $3^{\text {rd }}$ millennium BCE have revealed a lot about the collections of that period. At Elba, 20000 tablets have provided data on administration, language, geography and religion; and these early libraries had many elements of research collections, several centuries before Abraham, in the region spanning southern Mesopotamia and North-West Syria.

Later, the library at Ugarit was found in a building between the Temples of Baal and Dagon. A large number of Sumerian-Babylonian dictionaries were found; Sumerian being the ancient language of literature, while Babylonian was the language of commerce. Legal texts, medical treatises and treaties have been found, but the greatest number of Ugaritic tablets contained religious texts, mostly written when Nigmed, patron of the library was King of Ugarit in the middle of the $2^{\text {nd }}$ millennium.

One of the greatest libraries of the ancient world was created by Ashurbanipal (669-626 BCE) at Nineveh. Sir Francis Kenyon called this "the first great private collection of books known to history". Ashurbanipal sent scribes to all cit:es which possessed any documents of antiquity - Ashur, Babylon, Nippur and Akkad; and in some cases the king was so keen to see the contents that he opened the boxes himself as soon as they arrived in Nineveh! The collection comprised more than 20,000 tablets, kept on shelves and stored in buckets with clay labels. Tablets contained letters, contracts, sales, loans, astrology, law and literature. Documentary evidence is available of the beliefs, rituals and history of the Assyrians in the great days of the empire. They also appeared to have certain acquisition guidelines and most had cataloguing procedures. The practice at Nineveh was to record the author's name, followed by the father's and paternal grandfather's names, together with the measurement size of the text written and the number of lines, with the version of the text also recorded. It would appear that problems often arose similar to those of modern cataloguers!

Libraries in the sense of a collection of books for reference, teaching and educational reading appeared as early as the $6^{\text {th }}$ century BC in Greece. The earliest Greek libraries recorded are those of Polycrates on the island of Samos in $522 \mathrm{BC}$ and Peisistratus, ruler of Athens, in 606-527 BC. Peisistratus was a man of culture, who collected books and gave the public access to them and so had the distinction of establishing the first public library in Athens.

In the $4^{\text {th }}$ century $\mathrm{BC}$, libraries developed around the philosophical schools of Athens. The research undertaken by Aristotle's Lyceum in $336 \mathrm{BC}$ was facilitated by a library. It is 
thought that Plato's Academy also possessed a library. Beside these libraries there were a number of private collections of books, such as that owned by the dramatist, Euripides.

An inscription found on the island of Kos dated between 200-175 BC records the names of those who donated books to a library on the island. Another inscription of the same period refers to a plan to establish an appeal for donations of books and money followed by a list of subscribers' names. Part of a library catalogue has also been found on the island of Rhodes. Beside each recorded title was a number indicating the number of papyrus scrolls on which the work was written.

Papyrus, from which the modern word 'paper" is derived, was the common writing material of the ancient world. Grown along the banks of the Nile, strips of the stem were pounded together at right angles to make sheets which were fastened together to make a long strip which could be wound around sticks forming a scroll. As early as the $11^{\text {th }}$ century $\mathrm{BC}$, the Egyptians exported papyrus to other parts of the Mediterranean. Papyrus scrolls were used by the Greeks and the Romans from the $4^{\text {th }}$ century BC. One great advantage of papyrus was that, if it were kept dry, it was almost indestructible as there is very little moisture in the Nile Valley, anc so a large number of papyrus scrolls have survived. Although the scroll was an effective means of storing text, consulting the text could present problems. If what the readers required was at the end of the scroll, they had to roll thrcugh the entire scroll. However, unlike the clay tablets, scrolls were light and very easy to transport.

The conquests of Alexander the Great spread Hellenic culture over large areas of the east. Ptolemy I, one of Alexander's generals, became king of Egypt and lent his support to creating what was to become the greatest library in antiquity. Alexander died in June $323 \mathrm{BC}$, and five months later Ptolemy arrived in Egypt to take over the government. A competent commander

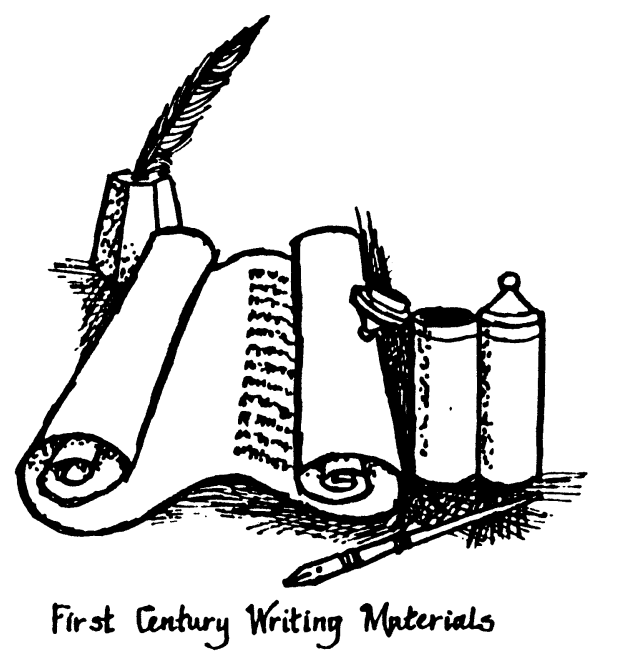
and shrewd and astute ruler, he knew that while Alexandria was a city of great power and wealth, he also wanted to make Alexandria a city of culture. His aim was to attract poets, philosophers, scientists and men of learning, who culd help create an Hellenic empire in Egypt.

1. Ptolemy's greatest claim to fame was the founding of the Alexandria Museum and Library. He enlisted the services of Demetrios Phalereus, a former Governor of Athens, to "collect if he could, all the books of the known world". In inducing Demetrios to come to Egypt, Ptolemy mad e an excellent choice. Of Demetrios, Diogenes Laertius was of the opinion "in learning and versatility he had no equal". He was a "dynamic thinker, a ripe and good scholar, a cultured Athenian man of letters".

Agents were sent out to scout all the cities of Asia, North Africa and Europe and were authorised to spend whatever money was necessary to obtain the desired manuscripts. Fla- 
vius Josephus (37-100 AD) wrote

Demetrius of Phalerium, who was in charge of the king's library, was anxious to collect, if he could, all the books in the inhabited world, and if he heard of, or saw, any book worthy of study, he would buy it; and so he endeavoured to meet the wishes of the king, for he was very devoted to the art of book collecting. Now, when Ptolemy once asked him how many thousands of books he had already gathered together, he replied that the present number was about 200,000 , but that within a short time he would assemble 500,000 . He added that he had been informed that among the Jews there were many works on their law, which were worthy of study and of a place in the king's library, but being written in the script and language of this people, they would be in no small trouble to have these translated into the Greek language.

Devious methods were used to procure books. Foreign ships calling at Alexandria were searched and books or manuscripts were confiscated when found. Copies were made, but the originals were retained for the library, and were catalogued under the special heading "Books of the Ships".

The main library of the "mother" library was housed near the royal palace in the Brachyuran, in the Greek quarter. The smaller of "daughter" library was established in an annexe attached to the Temple of Seraphis in the Egyptian quarter. These buildings housed the vast number of manuscripts collected, all of which had to be classified and catalogued. An estimation of the collection is reported to have been between 400,000 to 700,000 scrolls, but it is impossible to say how many works filled each scroll, since many works filled several scrolls.: The Iliad needed 24 scrolls, while other scrolls contained several short works. The Main Library consisted of ten great halls, with each hall assigned to a separate department of learning, embracing the assumed ten divisions of Hellenic knowledge as found in the catalogue of Callimachus. The halls were also used for general research by scholars, as well as there being a number of smaller rooms for those scholars engaged in special research.

The cataloguing of the library took place during the reign of Ptolemy II, by Callimachus of Cyrene, the third of the great librarians of the Alexandrian Library. When Ptolemy I died, his successor Ptolemy II "Philadelphus" (283 BC) removed Demetrios from his position as the first librarian of the Museum and Library. Demetrios was later banished to Upper Egypt where he was bitten by an asp and died. His successor was Zenodotus of Ephesus followed by Callimachus; who wrote the "Tables of all those who were eminent in any kind of literature and of their writings, in 120 books" or the famous Pinakes or tablets. These tablets were probably attached to the walls of the stacks, stating the name of the author whose works were grouped within the division for the type of literature. Each division was at least one Pinakes. He also gave the place of birth of the author, pseudonym, a short biography of the author, number of lines of the manuscript, scribe's name and often much more information. Thus the Pinakes were considered to be the first library catalogue of the civilised world.

For nearly two and a half centuries (205-48 BC) the Alexandrian Library was the reposi- 
tory of all known literature in the classical world. However, the first chapter in the eventual destruction of the magnificent library began in $48 \mathrm{BC}$, with the arrival in Egypt of Julius Caesar. Opinion amongst early historians differs as to whether the library was destroyed when Julius Caesar burned his fleet of ships in the harbour of Alexandria in $47 \mathrm{BC}$. Caesar could not afford to allow his ships to fall into the hands of his enemies, so he decided to set them afire. The wind blew the ships into the docks and waterfront property was destroyed. The main library was situated in the Serapeum and the Temple of Seraphis was on an acropolis, so it was highly unlikely the fire reached either of these two areas. However, it is known that approximately 40,000 papyrus rolls were destroyed in warehouses on the waterfront. The fact that books were stored in these temporary quarters has raised speculation that Caesar had made a selection of items and put them aside for shipment to Rome. It is known that Caesar had commissioned Marcus Varro to create a library in Rome at the same time as the fire in Egypt, so it is quite possible that these books had been destined for Rome.

2. Whatever manuscripts were lost were replaced by the ruthless pillage of the Pergamum Library after the city fell to Rome in $131 \mathrm{BC}$. An infatuated Mark Anthony robbed the library of 200,000 scrolls ca. $43 \mathrm{BC}$, which he gave to Cleopatra for the Alexandrian Library. Most historians agree that this took place, although it is labelled a rumour by Plutarch.

The actual destruction of the library is disputed, but it is thought to have taken place during the Arab conquest of Alexandria uncier 'Amr (642-646), when in order to establish the Muslim faith, the library and its contents were burned. The Alexandrian library, though physically destroyed, left an enduring legacy, as it became a prototype for national libraries throughout the world. It used bibliographic tools that are still used today to create order out of chaos in a large collection of material.

An exciting project is being undertaken, with the rebuilding of the Alexandrian Library on its original site. The Bibliotheca Alexandrina was originally to open in 1998 as part of an UNESCO project. However the latest date when work should be completed is Spring 2001. The project is estimated to cost US $\$ 172$ million, plus another US $\$ 182$ million for the land, Conference Centre, etc which has teen donated by the Egyptian Government. This and much more information can be found by visiting the website at www.unesco.org/webworld/ alexandria_new.

No historian knows exactly what the original library looked like, so an international competition has taken place which attracted 1400 entries from 77 countries. The winning plan chosen from Norway is a modern architestural design but will have the same aim as the original library, which was to "collect, store and develop sources of human intellect".

2. In Pergamum another library had begun under the enthusiastic patronage of King Eumenes II and competition began bitween the two cities. Pergamum (modern Bergama) is located $24 \mathrm{~km}$ inland from the Aegerin Sea and $110 \mathrm{~km}$ north of Smyrna (now Ismir). Situated in a spectacular position, ancient Pergamum crowned the acropolis and dominated the surrounding countryside, a fitting sit $\epsilon$ for the capital of a kingdom that at one time included all of western Asia Minor. This beautiful city with magnificent buildings and works of art, including a famous Altar of Zeus (now in the Pergamum Museum in Berlin), was regarded as by "far the noblest city in Asia Minor". (cf. Revelation 2: 2,4) 
Excavations in Pergamum have identified a building adjacent to the Temple of Athena as the library. The library comprised at least four rooms, with rows of holes in the back wall of the main hall as anchoring holes for wooden book shelves, with an estimated capacity of 17,740 scrolls. The adjoining rooms probably held an additional 50,000 scrolls altogether, so that the bulk of the holdings must have been stored elsewhere. The main hall was used as the reading room, which would also serve as a lecture hall. The design of the library, with its colonnaded reading / lecture room, may have served as the model for the earliest libraries in Rome, such as those built by Augustus in association with the temple of Apollo on the Palatine Hill. The Pergamum Library was built for general perusal by the public, and was therefore considered to be a prototype for later public libraries.

It was during the reign of Eumenes II (197-159 BC) that Crates of Mallos became the head of the Pergamene school and founded its school of grammar. Competition took place between Crates and his rival Aristarchus in Alexandria. Crates was also the librarian of the Pergameniana. $\mathrm{He}$ is thought to have compiled its famous catalogues of "Pinakes" of prose and poetical works. Many scholars were attracted to Pergamum. For the second time the Hellenic world was ransacked for manuscripts. Originals were more difficult to acquire and many copies and forgeries existed. It was quite probable the Library of Pergamum contained many faked manuscripts. Unless they were obvious forgeries, the librarians hesitated to refuse them in case they were snapped up by their rivals.

An enormous amount of papyrus was required for all the manuscript copies being produced. All the papyrus had to be

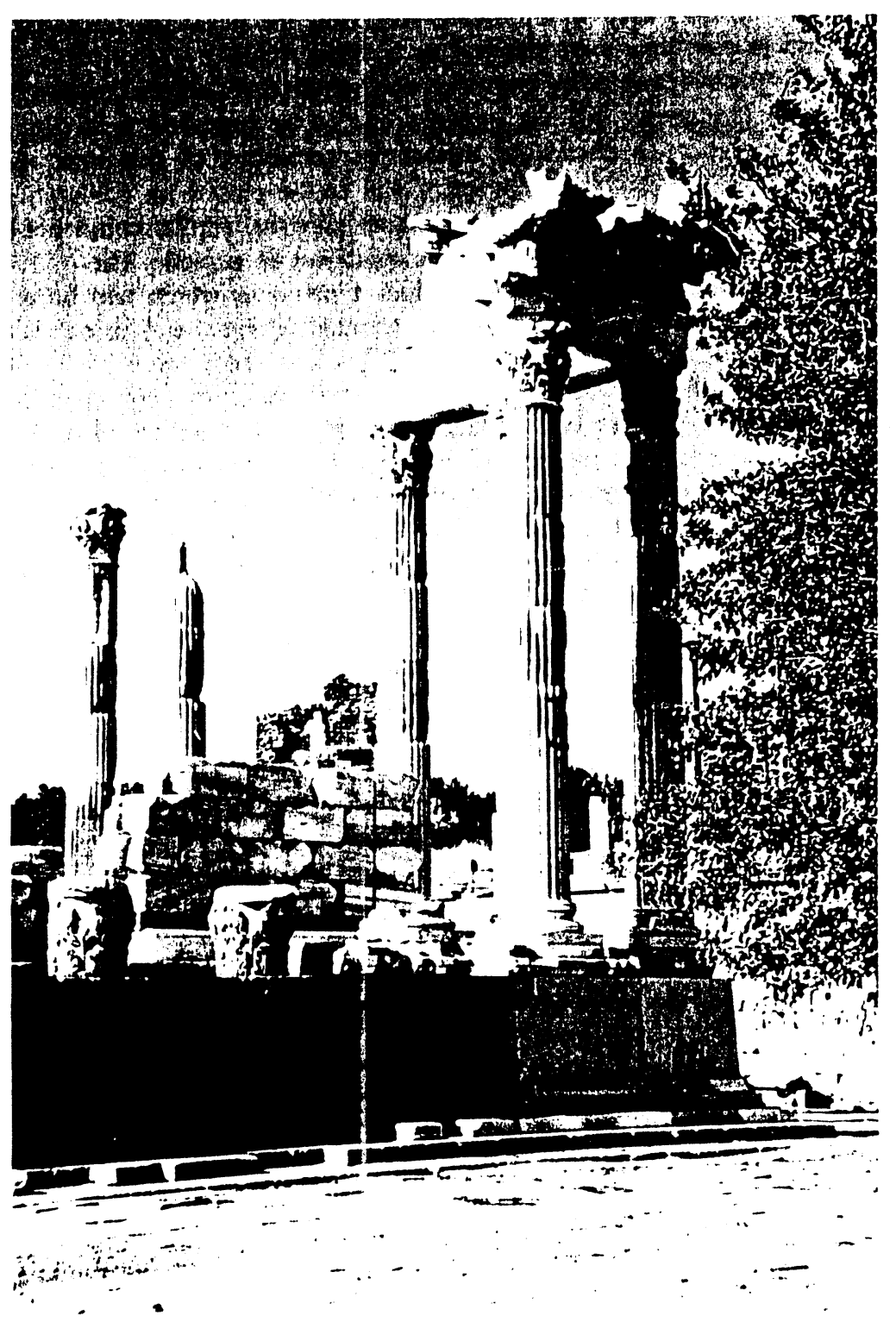

\section{Fergamum}

8 ANZTLA Newsletter no.40 
imported from Egypt. Ptolemy saw this as a chance to thwart the ambitions of this new rival library and to regard its literary progress and so he placed an embargo on the export of papyrus to Pergamum. Without papyrus, scrolls could not be produced, and without scrolls manuscripts could not be copied. The scholars of Pergamum were resourceful and a medium, which had been in partial use before, of making a form of parchment (Pergamene) using sheep and goat skins, or vellum was developed. This was much more costly, but very enduring. Although parchment was not an invention of Pergamum, it was there that the process was refined. The process consisted of soaking the skins in limewater, scraping off the hair, drying the skins on a frame and rubbing them with chalk and pumice stone and thus producing a fine material capable of being, written on both sides. The skins of sheep, goats and other animals were used for parchment; but for the finest parchment, vellum, calf skins were used.

Pergamum became recognised as the centre of production of the finest animal skins for writing, and it was not long before the sikins were called 'paper of Pergamum' or 'parchment'. As parchment could not be rolled like papyrus, the skins had to be placed on top of each other and so the 'codex' or book form as we know it today originated.

Mention has already been made of what Parsons has called "the greatest bibliographic rape and gift in all antiquity". When Antony gave the bulk of the Pergamum Library to Cleopatra - possibly because she demanded it in order to replace the books lost in the fire or for some other reason - the glorious era of the Pergamum Library concluded.

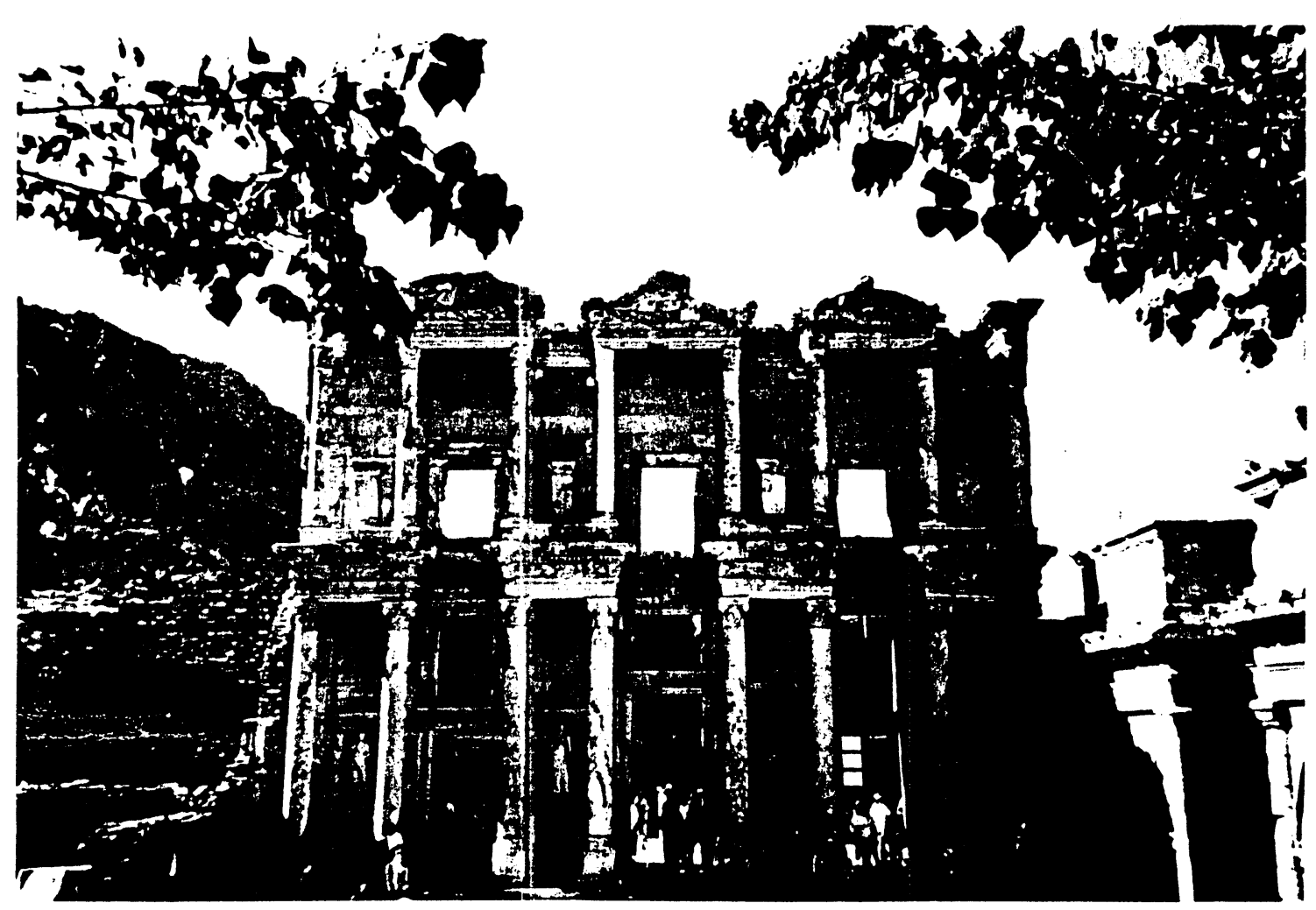

Library of Celsus, at Ephesus 
3. Third among the great libraries of the ancient world, after Alexandria and Pergamum is the Library of Celsus at Ephesus. Ephesus lay at the intersection of two major overland routes: the coastal road ran north through Smyrna (Ismir) and Pergamum to Troas (near ancient Troy) and the western route to Colossae, Hieropolis, Laodicea and beyond. Ephesus rose to become a religious and commercial centre and the Asiatic capital, in the place of Pergamum, and was one of the finest cities in the empire.

The Library building as you see it today has been reconstructed almost entirely by Austrian architects, with the help of fragments found during the excavations. The magnificent elaborately carved façade suggests the luxury of ancient Ephesus. Built during the Imperial Age and the time of Hadrian, the Library was erected in $110 \mathrm{AD}$ by the Consul Gaius Julius Aquila and dedicated to his lemaenus, a Roman senator left 25,000 denarii for the purof the library, which was comburied in a marble sarcophaLibrary.

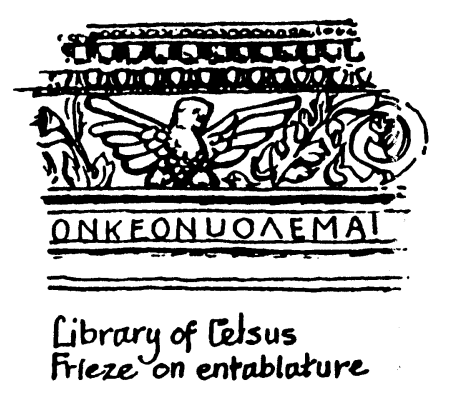
father Gaius Julius Celsus Poand Governor of Asia. Aquila chase of books and the upkeep pleted in $135 \mathrm{AD}$. Celsus lies gus in the substructure of the

These figures, to the left of the facade of the main entrance, represent:

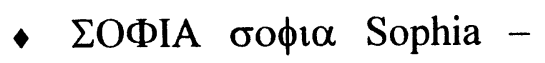
wisdom (cf. James 3.17)

- APETH $\alpha \rho \varepsilon \tau \eta$ arete - Virtue (cf. Philippians 4.8)

The two statues to the right of the entrance represent:

- ENNOIA \&vvor $\alpha$ ennoia intent, purpose, attitude of mind (cf Hebrews 4.12)

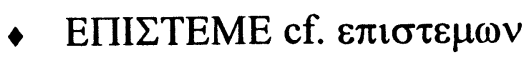
episteme - understanding, endued with knowledge, sensible (cf. James 3.13)
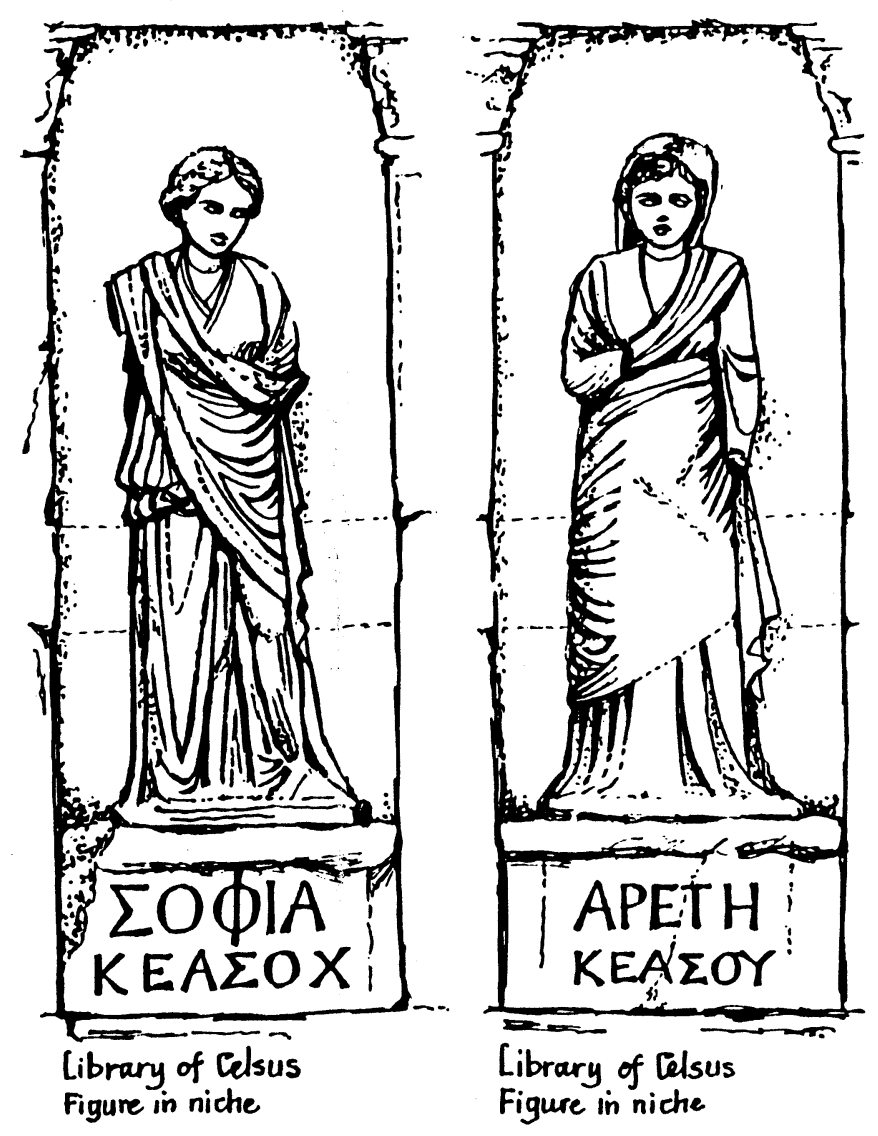

The four qualities might be summarised as wisdom, virtue, purpose and understanding, to be enhanced by thoughtful library use. 
The library was constructed on a raised platform. The entrance was through a courtyard paved with marble and then up broad steps, with magnificent statues on either side of the doorway. The main entrance led into the reading room, which had inner and outer walls, separated by passages, which helped to protect the books from humidity. The original arrangement of the interior of the library was three tiered and even today, in the ruins of the walls, niches can be seen where the manuscripts were stored. In the middle of the back wall there is a semi-circular niche. This was probably occupied by a statue of Athena, the patroness of wisdom and learning. The reading room was destroyed by fire during the second half of the third century, but the façade did not suffer damage.

Those who organised and administered these early libraries - some housed in exquisite architecture - facilitated the government, law, finance, trade, and education of their era; the communication and development of thought, scholarship, ideals and religious faith; and the well-being of their society: a heritage which librarians and information officers continue today.

Margaret Zarifeh is the Librarian at the Presbyterian Theological College, Box Hill North, Victoria. This article was written following a visit to the Middle East.

Reprinted with permission from The Christian Librarians' Network Newsletter, v.2, no.2, July 1997.

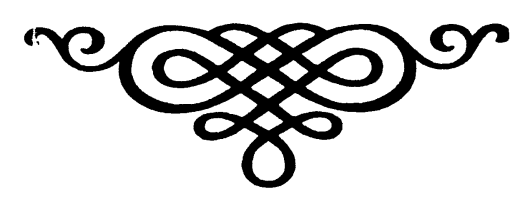

\section{Conferences in Britain this year}

Judith Powles, Chairman of AB'TAPL, sends the following news:

ABTAPL is hosting the annual conference of the Bibliotheques Europeenes de Theologie (BETH) in York from Wednesday $30^{\text {th }}$ August until Saturday $2^{\text {nd }}$ September 2000 . The BETH conference will be follow'ed immediately by ABTAPL's own conference which runs from Saturday until Monday $4^{\text {th }}$ September. BETH delegates will be invited to stay on for the ABTAPL proceedings. We are hoping that representatives from other theological associations may be able to join us, either for part or the whole of the time as the theme of the conference is

\section{Theological librarianship in an international context} and it would be good to have delegates from outside the European scene.

The conference has the full support of the staff of the British Library in Boston Spa (Yorkshire). One of the conference speakers will be Graham Cornish, a staff member at the British Library and President of the Library Association. Visits are planned to Ampleforth Abbey, York Minster Library and the British Library's Boston Spa site.

For full details of the conference and registration forms, contact Richard Ebdon, IFLA Offices for UAP, c/- The British Library, Boston Spa, Wetherby, LS23 7BQ, UK; email Richard.Ebdon@mail.bl.uk. 